\title{
Multidimensional Prediction Approach in the Assessment of Male Volleyball Players' Optimal Body Composition: The Case of Two Elite European Teams
}

\author{
Enfoque de Predicción Multidimensional en la Evaluación de la Composición Corporal Óptima \\ de los Jugadores de Voleibol Masculino: El Caso de Dos Equipos Europeos de Élite
}

\author{
Dopsaj Milivoj $^{1,2}$; Majstorovic Nikola ${ }^{1}$; Milic Radoje ${ }^{3}$; Nesic Goran ${ }^{1}$; Rauter Samo ${ }^{3}$ \& Zadraznik Marko ${ }^{3}$
}

DOPSAJ, M.; MAJSTOROVIC, N.; MILIC, R.; NESIC, G.; RAUTER, S. \& ZADRAZNIK, M. Multidimensional prediction approach in the assessment of male volleyball players' optimal body composition: the case of two elite European teams. Int. $J$. Morphol., 39(4):977-983, 2021.

SUMMARY: This research aimed to create a multidimensional equation for predicting an optimal body composition model for elite-level European male volleyball players. The subject sample consisted of 36 elite volleyball players: national team members from two European countries - Slovenia and Serbia - in the 2017 season. Measurement of body composition was carried out using electrical multichannel bioimpedance (BIA - InBody 720), in which 11 variables were used (body height as a longitudinal one, and the other 10 as a system of body composition indicators). Based on the results of descriptive statistics, we can state that elite European male volleyball players are tall, heavy, and with nutritional status at the level of $198.5 \pm 6.5 \mathrm{~cm}$, $92.3 \pm 5.9 \mathrm{~kg}$ and $23.44 \pm 1.44 \mathrm{~kg}^{\bullet-2}$, respectively. The percentage of body fat in the whole sample was $7.91 \pm 3.03 \%$, and the skeletal muscle mass index averaged $12.49 \pm 0.80 \mathrm{~kg}^{\bullet \mathrm{m}-2}$. For the evaluation and prediction of an optimal body composition model of elite male volleyball players, a multidimensional score (BC_Score) was defined, based on a simple, but sport-specific and playing position-sensitive model equation based on three dominant body characteristics of elite volleyball players: $\mathrm{BH}, \mathrm{PBF}$, and SMMI. In this manner, coaches can have a tool for managing the body composition status of players according to position, in terms of a deterministic, fully controlled system.

KEY WORDS: Bioimpedance; Volleyball; Body composition; Prediction.

\section{INTRODUCTION}

A proper body composition control system for athletes may improve their nutritional status to the most likely optimal level, and may help in competitive performance and monitor the 'applied training process efficiency', and thus is of major interest in preparation systems of elite competitive sports (Norton \& Olds, 2001; Santos et al., 2014).Volleyball consists of complex technical, tactical, and physical player requirements, which for high competition achievement players must be specifically adapted regarding morphological and body composition characteristics, as well as particular motor abilities and specific motor skills (Giannopoulos et al., 2017). Overall, in the game, a large number of various high intensity jumps, extremely fast short sprints, and high-intensity linear and non-linear complex movements repeatedly occur during each set (Sheppard $e t$ al., 2009; Giannopoulos et al.).

One of the most important parts in the system of the long-term training process in elite athletes' preparation is closely related to the effects of training type on morphological adaptations. However, the training type also dominantly depends on the type of sport. Today, in the sports science area, there are significant established findings regarding the relationship between physical abilities and specific motor characteristics with morphological type and body composition characteristics (Garthe et al., 2011; Ackland et al., 2012; Giannopoulos et al.; Saraykin et al., 2018; Zaric et al., 2020).

\footnotetext{
${ }^{1}$ University of Belgrade, Faculty of Sport and Physical Education, Belgrade, Serbia.

${ }^{2}$ South Ural State University, Institute of Sport, Tourism and Service, Chelyabinsk, Russia.

${ }^{3}$ University of Ljubljana, Faculty of Sport, Ljubljana, Slovenia.
} 
DOPSAJ, M.; MAJSTOROVIC, N.; MILIC, R.; NESIC, G.; RAUTER, S. \& ZADRAZNIK, M. Multidimensional prediction approach in the assessment of male volleyball players' optimal body composition: the case of two elite European teams. Int. J. Morphol., 39(4):977-983, 2021.

In addition to basic knowledge considering elite athletes' training technology, continuity of performance progress should also be achieved in the specific aspect of a given sport. Apart from the variables belonging to the basic and specific motor area, it is considered that certain morphological characteristics (i.e., sport-specific anthropomorphology characteristics) also have a significant influence on the achievement of success in volleyball. Elite volleyball players have exceptional body height, extremely low body fat level, high skeletal muscle percentage level, and generally long limbs with a dominantly mesomorphic body type (Palao et al., 2014; Bankovic et al., 2018; D' anastatio et al., 2019).

Elite volleyball players typically have an extremely intense and complex schedule with a great number of training sessions and games during the competitive season. Also, in the last decade, the popularization of volleyball at the global level has caused competitions to be organized around the world, which presents an additional extra effort for highly ranked national volleyball teams, independent of gender. It is considered that a great number of long journeys annually and frequent changes in time zones can lead to a biological rhythm disorder and, therefore, disrupt the athlete's body composition parameters (Bankovic et al.).

Therefore, adequate measurements and continuous body composition monitoring of elite volleyball players is an essential procedure, for nutritional-health reasons, for minimization and avoidance of injury and for maintaining players body structure in an optimal condition so they can respond to all of the performance demands (i.e., frequent and highly intensive training sessions and matches) (Garthe et al.; Nikolaidis et al., 2012; Saraykin et al.).

Finally, when analysing the descriptive profile of the body structure of the elite volleyball players, it can be concluded that body longitudinality, and the body fat and skeletal muscle are dominant anthropo-morphological characteristics. Considering the methodological aspect, the previously mentioned characteristics, as specific dimensions of the body composition, could be used to create mathematical models for assessing optimal body composition status. These models could be used for the screening purposes in the daily routine assessment process, as a sport-specific level, or even playing position-specific level control (Nikolaidis et al.; Santos et al.; Kukic et al., 2018; Dopsaj et al., 2019; Báez-San-Martín et al., 2019). Considering all the previously mentioned facts and the need to establish quick and sport-specific methods for assessing the body composition status of top volleyball players, this research aims to define a multidimensional model of optimal body composition screening for top volleyball players.

\section{MATERIAL AND METHOD}

Subjects. The subject sample consisted of 36 elite volleyball players aged $26.6 \pm 4.1$ years, with $13.8 \pm 3.3$ years of training experience. They were national team members from two European countries: Slovenia and Serbia. It should be noted that at the 2017 European Championships, the Serbian team finished in third place, while the Slovenian team finished eighth. However, at the 2015 European Championships, with the same team members, the Slovenian team finished in second place. Consequently, players of both teams can be categorized as elite European players. All players were informed about the measurement protocol and gave their consent to participate in this research. The research was carried out according to the Declaration of Helsinki (Christie, 2000), and it was approved by the Ethics Commission University of Belgrade (484-2).

Procedure. The study was organized according to a multicentric study procedure. All of the measurements were conducted in the lab, and in the same training period for both teams: during the final microcycle of the precompetitive stage of preparation for the 2017Men's EU Volleyball Championship (24 August - 03 September, Poland). Slovenian players were measured at the Faculty of Sport, University of Ljubljana, while the Serbian players were measured at the Faculty of Sport and Physical Education, University of Belgrade.

The study protocol was consisted of basic anthropometric parameters and body composition measurements according to procedures previously described earlier (Dopsaj et al., 2019; Bankovic et al.). Measurement of body height was performed using an anthropometer (GPM, Swiss made) with a measurement accuracy of 0.001 $\mathrm{m}$, while measurement of body composition was carried out using the method of electrical multichannel bioimpedance (BIA) with an InBody 720 body composition analysis device (Biospace Co., Ltd, Seoul, Korea). Following a day-off with no training, measurements were carried out before breakfast, between 08:00 and 09:00 in the morning.

Variables. In this study, 10 variables were used: one longitudinal, and nine as a system of body composition indicators. Considering body composition variables, three of which were primary, and six were derived (index) variables, divided into three categories: voluminously independent, longitudinally independent, and index variable (Santos et al.; Dopsaj et al., 2019; Kukic et al.). In this manner, the original variables of body mass, as a measure of total body mass quantity, skeletal muscle mass, as a measure of the contractile tissue amount, and fat mass, as a 
measure of the ballast tissue amount, are corrected with regards to the individual measure of body longitudinality and voluminosity. Those two measures, as a dominant body dimension characteristic in top volleyball players, are related in an inversely proportional ratio. Using that methodological approach, volleyball players' body composition characteristics were described using the individual bodyspecific dimensions approach for every single subject from the sample.

The original variables were:

1. BH - body height, as a basic body longitudinal variable, expressed in $\mathrm{cm}$,

2. BM - body mass, as a basic body volume variable, expressed in $\mathrm{kg}$;

3. FM - fat mass, as a total amount of fat (ballast) tissue mass in the body, expressed in $\mathrm{kg}$;

4. SMM - skeletal muscle mass, as a total amount of skeletal muscles (contractile) tissue mass in the body, expressed in $\mathrm{kg}$.

The longitudinally independent variables were:

5. BMI -body mass index, calculated as: $\mathrm{BM} / \mathrm{BH}^{2}(\mathrm{~m})$, expressed in $\mathrm{kg} \cdot \mathrm{m}^{-2}$;

6. BFMI- body fat mass index, calculated as: $\mathrm{FM} / \mathrm{BH}^{2}(\mathrm{~m})$, expressed in $\mathrm{kg} \cdot \mathrm{m}^{-2}$;

7. SMMI - skeletal muscle mass index, calculated as: SMM / $\mathrm{BH}^{2}(\mathrm{~m})$, expressed in $\mathrm{kg} \cdot \mathrm{m}^{-2}$.

The voluminously independent variables were:

8. $\mathrm{PBF}$ - percentage of body fat, calculated as: $\mathrm{BF} / \mathrm{BM}$, expressed in \%;

9. PSMM - percentage of skeletal muscle mass, calculated as: SMM/BMexpressed in \%.

The derived (index) variables were:

10. PFI - protein-fat index, calculated as relation between proteins (in $\mathrm{kg}$ ) and body fat mass (in $\mathrm{kg}$ ), expressed in $\mathrm{kg}$.

Statistical analysis. All data were subjected to descriptive statistical analysis to calculate basic measures of central tendency (MEAN), data dispersion (SD), data homogeneity - coefficient of variation ( $\mathrm{cV} \%)$, a minimum and maximum value (Min and Max), and upper and lower $95 \%$ confidence intervals of the mean. The normality of results distribution was determined by the application of the Shapiro-Wilk goodness-of-fit test with Lilliefors Significance Correction.
In the next step, Principal Component Analysis (Factor analysis) with direct Oblimin rotation and Kaiser normalization was used to reduce the set of morphological variables into factors. Thereafter, the most representative variable from defined factors was used in the second-order of analysis. Finally, from the extracted single factor, the standardized factor score was defined, which represented systematic information expressed as a score about the body composition of each subject from the sample. Then, the body height variable was transformed into $\mathrm{Z}$ score, and finally, in the last step, body composition score and body height score underwent to factor analysis again. The final score was obtained, representing the generated score value of the position of each individual in the explored sample regarding essential information about body composition and body height as an integral centroid score value. Lastly, mathematical modelling (i.e. multidimensional scaling) was used to transform the integral centroid value into a numerical analogy, meaning that the factor score of each subject was transformed into a proportional numerical score (BC_Score) on a linear scale (Dopsaj et al., 2010; Kukic et al.; Dopsaj et $a l ., 2019)$. For defining the equation for optimal body composition model of male volleyball male players, Multivariate Regression Analysis (MRA) was used.

In the end, the analysis of variance (ANOVA) was used to establish differences between players position BC_Score as a deterministic proof for specific sensitivity as an internal validity measure of a defined model equation. The level of statistical significance was defined based on criterion $\mathrm{p} \leq 0.05$ (Hair et al., 1998). All analyses were conducted using Microsoft Office Excel 2007 and IBM SPSS v23.0 statistical software.

\section{RESULTS}

In Tables I and II, basic descriptive variables statistics for the overall measured sample with statistical testing of the normality of the distribution, and results according to the playing position are shown.

The Kaiser-Meyer-Olkin measure of sampling adequacy value was determined to be 0.648 at a statistically significant level of $\mathrm{p}=0.000$, which indicates the statistically significant suitability of data for complex multidimensional statistical analysis. Factor analyses extracted two components (factors) with 61.06 and $27.41 \%$ (i.e. cumulative $88.47 \%$ ) of the explained variances of data. In the structure matrix, the first variables in the first extracted component (factor) were $\mathrm{PBF}$, and in the second component (factor) it was SMMI with 0.997 and 0.848 of saturated variance, respectively. 
DOPSAJ, M.; MAJSTOROVIC, N.; MILIC, R.; NESIC, G.; RAUTER, S. \& ZADRAZNIK, M. Multidimensional prediction approach in the assessment of male volleyball players' optimal body composition: the case of two elite European teams. Int. J. Morphol., 39(4):977-983, 2021.

Table I. Basic descriptive statistics of the overall sample and normality distribution results.

\begin{tabular}{|c|c|c|c|c|c|c|c|c|c|}
\hline \multirow{2}{*}{ Variables } & \multirow{2}{*}{$\begin{array}{l}\text { Mean } \\
(\mathrm{N}=36)\end{array}$} & \multirow{2}{*}{ SD } & \multirow{2}{*}{$\operatorname{cV}(\%)$} & \multirow{2}{*}{ Min } & \multirow{2}{*}{$\operatorname{Max}$} & \multicolumn{2}{|c|}{$\begin{array}{c}95 \% \text { Conf. Inter. of } \\
\text { Mean }\end{array}$} & \multicolumn{2}{|c|}{ Shapiro-Wilk } \\
\hline & & & & & & $\begin{array}{l}\text { Lower } \\
\text { Bound }\end{array}$ & $\begin{array}{l}\text { Upper } \\
\text { Bound }\end{array}$ & Statistic & $\mathrm{p}$-value \\
\hline $\mathrm{BH}$ & 198.5 & 6.5 & 3.27 & 184.0 & 213.0 & 196.3 & 200.7 & 0.956 & 0.167 \\
\hline BM & 92.3 & 5.9 & 6.39 & 78.4 & 104.0 & 90.3 & 94.3 & 0.983 & 0.845 \\
\hline $\mathrm{BF}$ & 7.33 & 2.88 & 39.29 & 2.50 & 12.20 & 6.35 & 8.30 & 0.950 & 0.102 \\
\hline SMM & 49.19 & 3.56 & 7.24 & 41.80 & 57.40 & 47.99 & 50.40 & 0.983 & 0.844 \\
\hline BMI & 23.44 & 1.44 & 6.14 & 20.62 & 26.52 & 22.96 & 23.93 & 0.935 & 0.034 \\
\hline BFMI & 1.87 & 0.76 & 40.64 & 0.64 & 2.96 & 1.62 & 2.13 & 0.934 & 0.033 \\
\hline SMMI & 12.49 & 0.80 & 6.41 & 10.85 & 14.25 & 12.22 & 12.76 & 0.987 & 0.943 \\
\hline PBF & 7.91 & 3.03 & 38.31 & 2.97 & 12.56 & 6.89 & 8.94 & 0.943 & 0.061 \\
\hline PSMM & 53.31 & 1.98 & 3.71 & 50.00 & 57.75 & 52.64 & 53.98 & 0.969 & 0.404 \\
\hline PFI & 2.858 & 1.561 & 54.62 & 1.381 & 6.593 & 2.330 & 3.387 & 0.813 & 0.000 \\
\hline BC_Score & 50.00 & 16.67 & 33.34 & 15.91 & 82.81 & 44.36 & 55.64 & 0.984 & 0.868 \\
\hline
\end{tabular}

Table II. Basic descriptive statistics of the tested variables according to the playing position (Mean \pm SD).

\begin{tabular}{lccccc}
\hline $\begin{array}{l}\text { Playing } \\
\text { Positions }\end{array}$ & Middle Blocker & Outside Hitters & Libero & Setter & Opposite Hitter \\
\hline Age & $25.5 \pm 3.4$ & $26.9 \pm 4.7$ & $27.5 \pm 3.8$ & $26.4 \pm 4.9$ & $25.9 \pm 5.1$ \\
BH & $203.8 \pm 4.1$ & $198.6 \pm 4.2$ & $190.4 \pm 5.1$ & $193.4 \pm 7.6$ & $199.9 \pm 2.9$ \\
BM & $93.4 \pm 7.0$ & $92.4 \pm 6.5$ & $87.8 \pm 2.5$ & $91.2 \pm 5.0$ & $95.3 \pm 4.3$ \\
BF & $7.24 \pm 2.86$ & $7.06 \pm 3.58$ & $8.92 \pm 1.82$ & $8.64 \pm 2.38$ & $5.2 \pm 1.6$ \\
SMM & $49.77 \pm 3.94$ & $49.37 \pm 2.86$ & $45.62 \pm 1.26$ & $47.82 \pm 2.67$ & $52.52 \pm 3.49$ \\
BMI & $22.48 \pm 1.33$ & $23.42 \pm 1.49$ & $24.23 \pm 0.63$ & $24.42 \pm 1.38$ & $23.85 \pm 1.29$ \\
BFMI & $1.75 \pm 071$ & $1.78 \pm 0.89$ & $2.45 \pm 0.45$ & $2.31 \pm 0.67$ & $1.30 \pm 0.44$ \\
SMMI & $11.98 \pm 0.71$ & $12.52 \pm 0.71$ & $12.59 \pm 0.58$ & $12.81 \pm 0.77$ & $13.14 \pm 0.92$ \\
PBF & $7.72 \pm 2.95$ & $7.49 \pm 3.51$ & $10.14 \pm 1.98$ & $9.44 \pm 2.55$ & $5.43 \pm 1.72$ \\
PSMM & $53.31 \pm 2.00$ & $53.52 \pm 2.11$ & $51.95 \pm 1.27$ & $52.45 \pm 1.63$ & $55.09 \pm 1.61$ \\
PFI & $2.838 \pm 1.475$ & $3.265 \pm 1.972$ & $1.848 \pm 0.464$ & $2.094 \pm 0.826$ & $3.869 \pm 1.586$
\end{tabular}

The results of the defined MRA model have shown that the final extracted factor explained $99.9 \%$ of the measured variance for BC_Score $\left({ }_{\mathrm{Adj}} \mathrm{R}^{2}=0.999\right.$, ANOVA of regression $\mathrm{F}=10772, \mathrm{p}=0.000$, Standard Error of the Estimate $=0.55$ ) showed extremely high predictive potential for the extracted model (Table III, BC_Score) considering the final factor iteration for longitudinal and body composition characteristics. The results of the BC_Score descriptive statistics, statistical differences between groups of players according to playing position, and defined mathematical equation as a model for prediction of elite volleyball players' optimal body composition are shown in Table III.

Table III. The BC_Score descriptive statistics, statistical differences between groups of players according to playing position, and mathematical model for prediction of elite volleyball players' optimal body composition.

\begin{tabular}{|c|c|c|c|c|c|c|c|c|c|}
\hline \multirow{2}{*}{ Playing Position } & \multirow{2}{*}{$\begin{array}{c}\text { Mean } \\
\text { (BC_Score) }\end{array}$} & \multirow{2}{*}{ SD } & \multirow{2}{*}{$\mathrm{cV}(\%)$} & \multirow{2}{*}{ Min } & \multirow{2}{*}{ Max } & \multicolumn{2}{|c|}{$\begin{array}{l}95 \% \text { Confidence } \\
\text { Interval of Mean }\end{array}$} & \multicolumn{2}{|c|}{ Shapiro-Wilk } \\
\hline & & & & & & $\begin{array}{l}\text { Lower } \\
\text { Bound }\end{array}$ & $\begin{array}{l}\text { Upper } \\
\text { Bound }\end{array}$ & Statistic & $\mathrm{p}$-value \\
\hline Middle Blocker & $56.93^{* *}$ & 16.22 & 28.49 & 20.03 & 76.02 & 46.03 & 67.83 & 0.911 & 0.252 \\
\hline Outside Hitters & $51.43 ¥$ & 10.46 & 20.34 & 38.57 & 71.60 & 43.95 & 58.91 & 0.936 & 0.506 \\
\hline Libero & 28.72 & 7.69 & 26.78 & 15.91 & 35.01 & 19.17 & 38.26 & 0.831 & 0.143 \\
\hline Setter & 38.90 & 14.26 & 36.66 & 24.57 & 54.46 & 21.19 & 56.61 & 0.856 & 0.214 \\
\hline Opposite Hitter & $64.27 \uparrow^{£}$ & 12.33 & 19.19 & 54.77 & 82.81 & 48.97 & 79.58 & 0.834 & 0.148 \\
\hline \multicolumn{10}{|c|}{ BC_Score: optimal body composition model equation } \\
\hline BC_Score & \multicolumn{9}{|c|}{$=-532.4494+(\mathrm{BH} \cdot 2.32075)-(\mathrm{PBF} \cdot 1.63806)+(\mathrm{SMMI} \bullet 10.70826)$} \\
\hline
\end{tabular}

**Libero vs Middle Blocker $-\mathrm{p}=0.004$; $¥$ vs Outside Hitter $-\mathrm{p}=0.033$; $\dagger$ vs Opposite Hitter $-\mathrm{p}=0.044 ; £$ Setter vs Opposite Hitter $-\mathrm{p}=0.044$. 
DOPSAJ, M.; MAJSTOROVIC, N.; MILIC, R.; NESIC, G.; RAUTER, S. \& ZADRAZNIK, M. Multidimensional prediction approach in the assessment of male volleyball players'optimal body composition: the case of two elite European teams. Int. J. Morphol., 39(4):977-983, 2021

The results of One-way ANOVA showed statistically significant differences between playing positions for BC_Score at $\mathrm{F}=6.534, \mathrm{p}=0.001$. Using Bonferroni Post-Hoc test between-group corrections, statistically significant differences were established between players at the positions liberos and middle blockers, outside hitters, respectively, and setters and opposite hitters (Table III). In Table IV, recommended quantitative normative values of BC_Score according to playing positions were presented by 7D model classes (Rakic et al., 2019).

Table IV. Recommended Qualitative-Normative values of examined BC_Score model for prediction of elite volleyball players' optimal body composition

\begin{tabular}{lccccc}
\hline $\begin{array}{l}\text { Position } \\
\text { BC-Score Classes }\end{array}$ & Middle Blocker & Outside Hitters & Libero & Setter & Opposite Hitter \\
\hline Superior & $\geq 89.40$ & $\geq 72.40$ & $\geq 44.15$ & $\geq 67.47$ & $\geq 88.98$ \\
Excellent & $73.17-89.39$ & $61.92-72.39$ & $36.44-44.14$ & $53.19-67.46$ & $76.63-88.97$ \\
Above Standard & $65.06-73.16$ & $56.68-61.91$ & $32.59-36.43$ & $45.05-53.18$ & $70.46-76.62$ \\
Standard & $48.82-65.05$ & $46.19-56.67$ & $24.87-32.58$ & $31.76-46.04$ & $58.10-70.45$ \\
Below Standard & $40.70-48.81$ & $40.95-46.18$ & $21.01-24.86$ & $24.62-31.75$ & $51.92-58.09$ \\
Bad & $24.47-40.69$ & $30.47-40.94$ & $13.30-21.00$ & $10.34-24.61$ & $39.57-51.91$ \\
Very Bad & $\leq 24.46$ & $\leq 30.46$ & $\leq 13.29$ & $\leq 10.33$ & $\leq 39.56$ \\
\hline
\end{tabular}

\section{DISCUSSION}

Body composition is a general indicator of the human organism condition because it is influenced by the effects of numerous factors, such as diet, health condition, level of physical activity, stress, and others (Chumlea et al., 2002; Garthe et al.). However, modern elite sport, there is a need to develop sport-specific, and even more, individual and playing positions sports-specific standards as the options for the future, whether it is a standard of body composition, some physical ability, or a level of the technical and tactical aspects of performance (Nikolaidis et al.; Dopsaj et al., 2017; Báez-San-Martín et al.; D’Anastasio et al., 2019; Zaric et al.).

Based on descriptive statistics results, we can assume that elite European male volleyball players are tall, heavy, and with nutritional status at the level of $198.5 \pm 6.5 \mathrm{~cm}$, $92.3 \pm 5.9 \mathrm{~kg}$ and $23.44 \pm 1.44 \mathrm{~kg} \cdot \mathrm{m}^{-2}$, respectively, which is in full accordance with previously published data for World and Olympic class of players (Sheppard et al.; Palao et al.).

According to the present study, we can state that the PBF level of the whole sample was $7.91 \pm 3.03 \%$ (Table I), with a range between $5.43 \pm 1.72 \%$ for opposite hitters, as a lower value, up to $10.14 \pm 1.98 \%$ for liberos (Table II), as the highest values. When we do compare mentioned results with the results from available literature, it can be concluded that elite European male volleyball has a much lower level of PBF compared to athletes from other sports, such as judokas - $11.31 \pm 3.96 \%$, Greco-Roman wrestlers $8.84 \pm 3.22 \%$, karatekas $-10.99 \pm 3.64 \%$ (Dopsaj et al., 2017), or general healthy male population of the same age $-21.8 \pm 6.2$ $\%$ (Chumlea et al.).
Considering SMMI elite European volleyball players have, on average, $12.49 \pm 0.80 \mathrm{~kg}$ of skeletal muscles per square metre of body height (Table I). According to playing position, the lowest level of skeletal muscles was observed for middle blockers $-11.98 \pm 0.71 \mathrm{~kg} \bullet \mathrm{m}^{-2}$, while higher levels were found at opposite hitters $-13.14 \pm 0.92$ $\mathrm{kg} \bullet \mathrm{m}^{-2}$ (Table II). Comparing SMMI results with the other athletes, it can be concluded that the longitudinally independent amount of skeletal muscle mass is in line with athletes in other strength and power-dependent sports, such as judokas - $13.11 \pm 1.25 \mathrm{~kg} \bullet \mathrm{m}^{-2}$, Greco-Roman wrestlers $13.88 \pm 1.25 \mathrm{~kg} \cdot \mathrm{m}^{-2}$ and karatekas- $11.75 \pm 0.97 \mathrm{~kg} \cdot \mathrm{m}^{-2}$ (Dopsaj et al., 2017).

Analysing the results of factor analyses, two factors were extracted. The most important variable from factor one was PBF, as a variable that represents voluminosity independent content of fat in the body, and the most important variable from factor two was SMMI, as a longitudinally independent content of skeletal muscle mass in the body. Such results are quite logical and completely in line with the practical need of volleyball as a sport, where player's body profile is dominantly shaped in a function of very tall persons with a very low percentage of body fat, and proportionally distributed muscle mass relative to body height (i.e. as a basic body dimension longitudinality).

By analysing the latest data from the performance analysis, it seems that, as a game, volleyball strategically develops in the following three directions: maximizing all aspects of height in the game (taller players and better jumping abilities of players), maximizing all speed aspects 
of the game (serve or spike speed and faster technical-tactical game action performance) and increasing performance efficiency (Shephard et al.; Palao et al.; Bankovic et al.).

Consequently, an athlete's anthropo-morphological and body composition adaptations to new training and competitive conditions occur in a parallel time frame. Considering the results of the present study, it can be concluded that the most important factors that characterize elite European male volleyball players' body composition model, besides remarkable basic body longitudinality (i.e., body stature), are body composition based on a very small amount of body fat regardless of the overall body mass, and a pronounced amount of skeletal muscle mass regardless of the body longitudinality.

Consequently, volleyball is a game dominated by short-lasting submaximal and maximal efforts with a great number of repetitions of high standing and running jumps, with the extremely represented fast and extremely fast (almost reflex reactions) simple movements, as well as short, complex and rapid agile actions, all performed in the anaerobic alactic (ATP+CP) energetic zone (single actions), but generally, in the aerobic type of effort (observing the whole game). It seems that selection and adaptation of players' body composition, regardless of gender, is shifted to tall (libero and setter), or very tall (middle blocker, opposite hitter and outside hitter) mesomorphic body type persons regardless of playing position (Palao et al.; Bankovic et al.).

In sports that require powerful, explosive movements, the skeletal muscle mass per square metre of body height is an indicator of a body's contractile substance, which represents a biological basis for the quality manifestation of sports movement properties. Thus, in elite volleyball performance level, it seems that it is important for the SMM per square metre of body height to be at an optimal level, between 11 to $14 \mathrm{~kg} \cdot \mathrm{m}^{-2}$, and BF between 5 to $10 \%$ of overall body mass, for player's optimal sport-specific abilities to respond to the short, fast and intensive performance demands during the match.

Results of ANOVA showed the specific sensitivity of the defined BC_Score mathematical model of prediction, because a statistically significant difference in detection anthropo-body-composition characteristics between players on different playing positions was found. Generally speaking, it seems that two typical body subtypes were: as well as middle blocker, outside and opposite hitter, as the players with BC_Score above 50.0 (56.93, 51.43 and 64.27, respectively), and libero and setter with BC_Score under 50.0 (28.72 and 38.90, respectively, Table III).
Finally, with the BC_Score, optimal body composition model for elite European male volleyball players can be easily determined. By a very simple, but sport-specific and playing position-sensitive model equation based on three dominant body characteristics of elite volleyball players ( $\mathrm{BH}, \mathrm{PBF}$, and $\mathrm{SMMI})$, it is possible to estimate the actual body composition status of the player relative to the defined standards (Table IV). Also, the defined model provides the possibility of designing and programming the necessary player body status changes in terms of body structure optimization. In that way, coaches can have a useful tool for player's body composition status management according to position, in terms of a deterministic and fully controlled system. These findings emphasize the need for coaches to understand the intra individual dissimilarities between the players and to use this information when designing all types of volleyball strength and conditioning training programs (Nikolaidis et al.; Palao et al.; Saraykin et al.).

\section{CONCLUSION}

To quantify the body status of elite-level European male volleyball players, an optimal body composition score was calculated based on three body characteristics, extracted with factor analyses: BH, PBF, and SMMI.

In addition to the sports-specific validity, the results showed that the defined BC_Score model is specifically sensitive considering the playing position. With the method of mathematical modelling that was applied, two typical body subtypes were established: as well as middle blocker, outside and opposite hitter, at the players with BC_Score above 50.0, and libero and setter with BC_Score under the 50.0.

Part of this research's significance is due to its sample of subjects. The research was conducted on elite European volleyball players and provides a much more accurate and detailed notion about elite athlete's body composition. Thus, at present, the results of the study could serve as reference values applicable in volleyball practice until future research provides the next relevant information about the same topic.

\section{ACKNOWLEDGEMENTS}

The paper is a part of the project III47015, funded by the Ministry of Education, Science and Technological Development of the Republic of Serbia, 2011-2020. 
DOPSAJ, M.; MAJSTOROVIC, N.; MILIC, R.; NESIC, G.; RAUTER, S. \& ZADRAZNIK, M. Enfoque de predicción multidimensional en la evaluación de la composición corporal óptima de los jugadores de voleibol masculino: el caso de dos equipos europeos de élite. Int. J. Morphol., 39(4):977-983, 2021.

RESUMEN: Esta investigación tuvo como objetivo crear una ecuación multidimensional para predecir un modelo de composición corporal óptimo para los jugadores de voleibol masculinos europeos de élite. La muestra consistió en 36 jugadores de voleibol de élite, miembros del equipo nacional de dos países, Eslovenia y Serbia, en la temporada 2017. La composición corporal se realizó mediante bioimpedancia eléctrica multicanal (BIA InBody 720), en la que se utilizaron 11 variables (la altura corporal como longitudinal y las otras 10 como sistema de indicadores de composición corporal). Con base en los resultados de las estadísticas descriptivas, observamos que los jugadores de voleibol de élite europeos son altos, pesados y con un estado nutricional de $198,5 \pm 6,5 \mathrm{~cm}, 92,3 \pm 5,9 \mathrm{~kg}$ y $23,44 \pm 1,44 \mathrm{~kg} \bullet \mathrm{m}^{-2}$, respectivamente. El porcentaje de grasa corporal en toda la muestra fue de $7,91 \pm 3,03 \%$ y el índice de masa del músculo esquelético promedió $12,49 \pm 0,80 \mathrm{~kg} \cdot \mathrm{m}^{-2}$. Para la evaluación y predicción de un modelo de composición corporal óptimo de jugadores de voleibol masculino de élite, se definió una puntuación multidimensional (BC_Score), basada en una ecuación de modelo simple, pero específica del deporte y sensible a la posición de juego, basada en tres características corporales dominantes de la élite. Jugadores de voleibol: BH, PBF y SMMI. De esta manera, los entrenadores pueden disponer de una herramienta para gestionar el estado de la composición corporal de los jugadores según la posición, en términos de un sistema determinista y totalmente controlado.

PALABRAS CLAVE: Bioimpedancia; Voleibol; Composición corporal; Predicción.

\section{REFERENCES}

Ackland, T. R.; Lohman, T. G.; Sungot-Borgen, J.; Maughan, R. J.; Meyer, N. L.; Stewart, A. D. \& Müller, W. Current status of body composition assessment in sport. Sport. Med., 42(3):227-49, 2012.

Báez-San-Martín, E.; Jil-Beltrán, K.; Ramírez-Campillo, R.; Tuesta, M.; Barraza-Gómez, F.; Opitz-Ben-Hour, A. \& Yáñez-Sepúlveda, R. Body composition and somatotype of Chilean rugby players and their relationship with the game position. Int. J. Morphol., 37(1):331-7, 2019.

Bankovic, V.; Dopsaj, M.; Terzic, Z. \& Nesic, G. Descriptive body composition profile in female olympic volleyball medalists defined using multichannel bioimpedance measurement: Rio 2016 team case study. Int. J. Morphol. 36(2):699-708, 2018.

Christie, B. Doctors revise Declaration of Helsinki. BMJ, 321:913, 2000.

Chumlea, W. C.; Guo, S. S.; Kuczmarski, R. J.; Flegal, K. M.; Johnson, C. L.; Heymsfield, S. B.; Lukaski, H. C.; Friedl, K. \& Hubbard, V. S. Body composition estimates from NHANES III bioelectrical impedance data. Int. J. Obesity, 26(12):1596-609, 2002.

D’Anastasio, R.; Milivojevic, A.; Cilli, J.; Icaro, I. \& Viciano, J. Anthropometric profiles and somatotypes of female volleyball and beach volleyball players. Int. J. Morphol., 37(4):1480-5, 2019.

Dopsaj, M.; Copic, N.; Nesic, G. \& Sikimic, M. A simple mathematical model for estimating general jumping preparedness of senior female volleyball players. Exerc. Qual. Life, 2(2):63-74, 2010.
Dopsaj, M.; Markovic, M.; Kasum, G.; Jovanovic, S.; Koropanovski, N.; Vukovic, M.; Mudric, M. Discrimination of different body structure indexes of elite athletes in combat sports measured by multi frequency bioimpedance method. Int. J. Morphol., 35(1):199-207, 2017.

Dopsaj, M.; Nenasheva, A. V.; Tretiakova, T. N.; Syromiatnikova, Y. A.; Surina-Marysheva, E. F.; Markovic', S. \& Dopsaj, V. Handgrip muscle force characteristics with general reference values at Chelyabinsk and Belgrade students. Hum. Sport Med., 19(2):27-36, 2019.

Garthe, I.; Raastad, T.; Refsnes, P. E.; Koivisto, A. \& Sundgot-Borgen, J. Effect of two different weight-loss rates on body composition and strength and power-related performance in elite athletes. Int. J. Sport Nutr. Exerc. Metab., 21(2):97-104, 2011.

Giannopoulos, N.; Vagenas, G.; Noutsos, K.; Barzouka, K. \& Bergeles, N. Somatotype, level of competition, and performance in attack in elite male volleyball. J. Hum. Kinet., 58:131-40, 2017.

Hair, J.; Anderson, R.; Tatham, R. \& Black, W. Multivariate Data Analysis. $5^{\text {th }}$ ed. New Jersey, Prentice-Hall Inc., 1998.

Kukic, F.; Dopsaj, M.; Dawes, J.; Orr, R. \& Cvorovic, A. Use of human body morphology as an indication of physical fitness: implications for police officers. Int. J. Morphol., 36(4):1407-12, 2018.

Nikolaidis, P. T.; Ziv, G.; Arnon, M. \& Lidor, R. Physical characteristics and physiological attributes of female volleyball players-The need for individual data. J. Strength Cond. Res., 26(9):2547-57, 2012.

Norton, K. \& Olds, T. Morphological evolution of athletes over the 20th century: causes and consequences. Sports Med., 31(11):763-83, 2001.

Palao, J. M; Manzanares, P. \& Valadés, D. Anthropometric, physical, and age differences by the player position and the performance level in volleyball. J. Hum. Kinet., 44:223-36, 2014.

Rakic, S.; Dopsaj, M.; Djordjevic-Nikic, M.; Vasiljevic, N.; Dopsaj, V.; Maksimovic, M.; Tomanic, S. M. \& Miljus, D. Profile and reference values for body fat and skeletal muscle mass percent at females, aged from 18.0 to 69.9 , measured by multichannel segmental bioimpedance method: Serbian population study. Int. J. Morphol., 37(4):1286-93, 2019.

Santos, D. A.; Dawson, J. A.; Matias, C. N.; Rocha, P. M.; Minderico, C. S.; Allison, D. S.; Sardihna, L. B. \& Silva, A. M. Reference values for body composition and anthropometric measurements in athletes. PLoS One, 9(5):e97846, 2014.

Saraykin, D. A.; Khusnutdinova, A. A.; Pavlova, V. I.; Kamskova, Y. G. \& Yushkov, B. G. Adaptation of professional athletes to various physical loads by means of body composition changes. Hum. Sport Med., 18(3):47-59, 2018.

Sheppard, J. M.; Gabbett, T. J. \& Stanganelli, L. C. R. An analysis of playing positions in elite men's volleyball: considerations for competition demands and physiologic characteristics. J. Strength Cond. Res., 23(6):1858-66, 2009.

Zaric, I.; Dopsaj, M.; Markovic, M.; Zaric, M.; Jakovljevic, S. \& Beric, D. Body composition characteristics measured by multichannel bioimpedance in young female basketball players: relation with match performance. Int. J. Morphol., 38(2):328-35, 2020.

Corresponding author:

Dr. Marko Zadraznik

Univerza V Ljubljani

Fakulteta za sport

Gortanova 22

1000 Ljubljana

SLOVENIA

E-mail: marko.zadraznik@fsp.uni-lj.si

Received: 22-03-2021

Accepted: 27-04-2021 